\title{
Sociology of Multiracial Identity in the Late 1980s and Early 1990s: The Failure of a Perspective
}

\author{
G. Reginald Daniel \\ University of California, Santa Barbara
}

\begin{abstract}
Sociologists largely failed to comprehend the emergence of multiracial identities in the United States during the late 1980s and early 1990s. This was due, in part, to hypodescent and the monoracial imperative. These social devices, respectively, categorize offspring of interracial unions between Whites and people of color based exclusively on the background of color, and necessitate single-racial identification. This has prohibited the articulation and recognition of multiracial identities. Hypodescent and the monoracial imperative are so normative that they have been taken for granted by sociologists across the monoracial spectrum, much as the larger society. Sociology's espoused objectivity blinded sociologists to the standpoint of their own monoracial subjectivity. They provided little critical examination of hypodescent and the monoracial imperative in terms of their impact on multiracial identity formations. Some sociologists challenged theories of marginality, which stressed the psychological dysfunction of multiracials. Yet multiracial identities were considered symptomatic of mainly isolated psychological concerns with personal identity. Sociologists were absent from analyses of collective identity and agency speaking to mixed-race concerns. Consequently, they remained on the periphery of social scientific theorizing of multiracial identities in terms of their wider-ranging implications.
\end{abstract}

Keywords: group formation, hypodescent, mixed race, multiracial, sociological theories of race, the one-drop rule.

\section{Introduction: The Failure in Historical Perspective}

McKee (1993), in Sociology and the Race Problem: The Failure of a Perspective, argued most U.S. sociologists of race relations failed to chart the trajectory that emerged in the 1950s and 1960s. Specifically, they did not foresee Blacks emerging as autonomous political actors in the civil rights struggle. Blacks supposedly lacked the sociocultural capital to commandeer a movement for their own liberation. This myopia was also attributable to the prevailing orderfunctionalist paradigm that disregarded and disparaged conflict as a meaningful tool for bringing about social structural change (Blauner, 1972; Horton, 1966; McKee, 1993; Steinberg, 2007). The order-functional paradigm envisioned the integration of Blacks into the larger society in a manner similar to that of European immigrants, however much in the distant future. This would be accomplished through gradual, piecemeal, and above all peaceful, reform, not radical transformation. Whites would be at the helm of collaborative initiatives with "sober-minded" Blacks to achieve this goal (Feagin \& Feagin, 2012; McKee, 1993).

Blauner (1972), Ladner (1973), and others argued this failure to anticipate the AfricanAmerican civil rights movement is attributable to a perspective constructed by and reflecting the

\footnotetext{
${ }^{1}$ This subtitle borrows from McKee (1993).

${ }^{2}$ Corresponding Author E-Mail: rdaniel@soc.ucsb.edu
} 
standpoint and White racial subjectivity of elite European American male sociologists who dominated the discipline. Racial subjectivity is the specific way individuals are informed by and interact with the racial dynamics of the world they inhabit. This includes the social and cultural processes of race relations as well as the political economy (Enstad, 1999). Individuals' racial standpoint is impacted by their racial group membership and is a product of a group's history in a given society (Kinefuchi \& Orbe, 2008). Sociologists' supposed value-free sociology was, in fact, implicitly and explicitly value-laden with White racist and White supremacist biases of the larger society from its institutionalization in the 1890s well into the 1960s, and so normative and common sense that they were taken for granted (Blauner, 1972; Ladner, 1973; McKee, 1993).

Blauner, Steinberg, and Ladner maintained the sociological establishment was even more taken off guard by the radical insurgency of the Black power movement, Black nationalism, and violent urban uprisings in the late 1960's and early 1970's. Their agenda not only espoused immediate social transformation rather than gradual reform, but also jettisoned integration as a goal. Instead, Blacks were viewed as a plural society and culture separate from that of Whites (Blauner, 1972; Ladner, 1973; Ringer, 1983; Steinberg, 2007). Beginning in the early 1970s, Blauner and others reckoned with these developments in the power-conflict framework (Feagin \& Feagin, 2012; Horton, 1966). This paradigm emphasized the historical and contemporary structural obstacles placing Blacks and other groups of color disproportionately at the bottom of society. Their experience was considered significantly different from that of Whites in terms of their overall structural inclusion and social advantages (Telles \& Sue, 2020).

Power-conflict theories also point out the pursuit or accomplishment of integration among communities of color in terms of structural equity in the political economy and other areas of the public sphere, did not necessarily indicate a desire or ability to achieve cultural integration in a manner similar to European immigrants and their descendants (Blauner, 1972; Gurer, 2019; Ladner 1973; Rodríguez-García, 2015; Song, 2009; Steinberg, 2007). That integration included embracing Anglo-American values, behaviors, beliefs, customs, and artefacts to the exclusion of their own core culture (Telles \& Sue, 2020). Anglo-Americanization encompasses, among other things, reification of private property and private enterprise, as well as viewing electoral politics rather than radical and revolutionary insurgency, as the primary means of political change (Cheeseboro, 1999).

Integration also does not necessarily indicate a desire or ability to racially integrate into the larger (and ostensibly White) mainstream, at least as deracinated "others," subsequent to increased interracial marriage, even if it were available. Instead, the possibility of racial integration is the final and most visible step. Taken to its conclusion, this type of integration, along with cultural integration, would lead to erasure of the particularity of Blacks and other communities of color (Alba, 2009, 2020; Armstrong, 2019; Bonilla-Silva, 2003; Gans, 2012; Newman, 2020; RodríguezGarcía, 2015; Song, 2009; Telles \& Sue, 2020).

Given that sociologists historically defined the race problem as the "Negro problem," they were even less attentive to civil rights or nationalist movements among other communities of color such as "brown power" among Latinas/os, "red power" among Native Americans, and "yellow power" among Asian Americans (Omi \& Winant, 1994). Juan Perea (1997) attributes this omission to the Black-White binary, which has historically tended to marginalize the racial experiences of these and other nonWhite groups. Their experiences have instead, typically been framed and understood by the Black-White polarity. O'Brien refers to these groups as the "racial middle" (O'Brien, 2008) based on the racial and, to some extent, cultural markers that differentiate them from Whites and Blacks (Alcoff, 2006; Gines, 2013; Kim, 1999).

Borrowing on O'Brien's concept, I maintain U.S. sociologists have historically largely omitted deliberations on the "mixed racial middle." By virtue of this exclusion, sociologists lacked 
a meaningful framework for studying experiences informed by identifications with ancestral (and cultural) ties to both White and nonWhite, or several nonWhite, racial groups. Thus, much as they failed to anticipate developments in the 1950s and 1960s, sociologists were unprepared for and unable to comprehend the emergence of multiraciality as the basis for identity formations beginning in the late 1980s and early 1990s (Daniel et al., 2014; Newman, 2020). This failure is credited to a standpoint informed by hypodescent and the monoracial imperative. ${ }^{3}$ These social devices, respectively, categorize multiracials according to their most subaltern racial background and necessitate monoracial (single-racial) identification. This has disallowed, and indeed repressed, the articulation and recognition of multiracial identities, that is, identification with more than one racial background (Davis, 2001).

\section{Hypodescent and the Monoracial Imperative: Excluding the Mixed Racial Middle}

Sociologists provided little critical examination of the social forces preventing multiracial identity formations. Instead, monoraciality and hypodescent were taken for granted. Much as the larger society, sociologists across the monoracial spectrum, who dominated the discipline, internalized norms of the U.S. racial order while their espoused objectivity blinded them to their own monoracial subjectivity and positionality (Horton, 1966). Sociologists' assumed value-free ethos was, in fact, imbued with inherent monoracial biases that have permeated the discipline since its inception and institutionalization in the 1890s (Blauner, 1972; Ladner, 1973; McKee, 1993; Steinberg, 2007).

English Americans began enforcing hypodescent and the monoracial imperative during the late $17^{\text {th }}$ and early $18^{\text {th }}$ centuries to maintain social divisions between themselves as the dominant "White" group and subaltern "nonWhite" groups. Hypodescent has thus buttressed a binary racial order that broadly necessitates identification as either White or nonWhite. It was implemented as part of antimiscegenation legislation regulating interracial intimacy, specifically interracial marriages, and defining as nonWhite any progeny born of these relationships. Black-White relations were the most common targets of these statutes and suffered the most severe restrictions (Murray, 1997).

In the 1660s, Virginia authorities enacted laws to deter interracial intimacy and to punish Black/White children, that is, mulattoes, with prolonged servitude. Beginning in the 1690s, Maryland and other colonies followed Virginia's lead. Notably, antimiscegenation legislation was initially concerned with interracial relations and marriages between European women - particularly indentures - and enslaved men of African descent. The earliest laws did not actually forbid interracial marriages. Rather, they sought to deter them by imposing stiff fines or severe penalties including banishment, whippings, and additional terms of servitude for the women. They also stipulated children born of these marriages would be indentured (Davis, 2001).

By the mid-eighteenth century, Black-White marriages in the Southern and some Northern colonies were stigmatized where they were not legally prohibited. Black male-White female unions, whether casual, common-law, or legalized in marriage, were strictly forbidden. These relationships threatened the sanctity of White womanhood and the integrity of the White family, which were pivotal to preserving White racial "purity" (Douglas, 1966) and numerical self-perpetuation, as well as the intergenerational transmission of White wealth, power, privilege, and prestige (Davis, 2001). The key difference, however, was found in public attitudes (Nash, 2014), which continued to tolerate sexual assault and extended concubinage involving White men and women of African descent. Those unions

\footnotetext{
${ }^{3}$ Harris (1964) coined the term "hypodescent" referring the one-drop rule, which designates as black anyone with "one-drop of African blood." In principle, hypodescent is applicable to degrees of ancestry less restrictive than the one-drop rule in terms of blackness as well as to all mixed-race combinations.
} 
had no legal standing, posed little threat to slave-based racial order, and would become the source of most subsequent miscegenation (Spickard, 1989).

Moreover, these men typically disavowed their mulatto offspring from these relationships. Indeed, hypodescent conveniently exempted White landowners (particularly slaveholders) from the legal obligation of passing on inheritance and other benefits to their multiracial children. Hypodescent did not, however, increase the numbers of slaves. Multiracial offspring were slaves, contingent upon the status of the mother, not hypodescent. Rather, hypodescent increased the numbers of Blacks, whether slave or free. The Anglo-American patriarchy thus found the ideal solution to its labor needs, extramarital sexual behaviour, and obsession with protecting White racial purity, as well as economic and political power (Nash, 2014). The ramifications of hypodescent reached momentous proportions with the institutionalization of Jim Crow segregation at the turn of the twentieth century. This legally sanctioned the unequal treatment of Blacks and other communities of color in most aspects of social life (Davis, 2001).

Davis (2001) argued hypodescent has been applied most stringently to first-generation offspring. But it is less applicable to those with Latina/o ancestry, Asian American ancestry (Spickard, 1989), and Native American ancestry, especially those without connections to Native American reservations (Wilson, 1992). Frequently, these individuals and successive generations have been allowed flexibility in terms of their self-identifications. Jordan (2014) maintained this flexibility has not extended to individuals of African and European descent, whether first-generation or later. They have instead, experienced the most restrictive rule of hypodescent - the one-drop rule — which designates as Black all individuals with any African ancestry. Unique to the United States and only applied to individuals of African descent, this device has historically precluded self-identification and ensured that all future descendants with African ancestry have been designated and have self-identified as solely Black. It gained currency as the commonsense definition of Blackness between the $17^{\text {th }}$ and $19^{\text {th }}$ centuries (Davis, 2001) but did not become a customary part of the legal apparatus until the early twentieth century (circa 1915).

U.S. attitudes toward the "dual minority" offspring of African Americans and other groups of color have varied (Forbes, 1988; Loewen, 1971). All have generally been subject to the one-drop rule and monoracial formations but greater ambivalence is displayed toward non-Black dual minority offspring such as Asian Indian/Mexican Americans ("Punjabi Mexicans") (Leonard, 1992) and Filipino/Mexican Americans ("Mexipinos") (Guevarra, 2012). These groups occupy a more ambiguous position in the U.S. racial hierarchy with membership less clearly defined in law. Hypodescent still tends to push these dual-minority multiracials toward the less privileged background in the racial hierarchy, though the most subaltern background can vary situationally. Moreover, in each instance, monoracial norms have historically disallowed the articulation and recognition of multiracial identities.

Hypodescent, particularly the one-drop rule, and the monoracial imperative, are the cornerstones of the U.S. binary racial order. Lipsitz maintained the resulting "possessive investment" in Whiteness (Lipsitz, 1998, p. 2) has been critical to maintaining White racism and racial privilege despite increasing repudiation beginning in the 1960s and 1970s of notions of White racial purity and White supremacy. White racism leads to significantly different life chances and overall quality of life along racial lines, including grossly inequitable access to education, employment, health care, transportation, and housing, etc. These outcomes are not merely the byproducts of benign neglect. Rather, they are the accumulation of the purposeful designs of Whites that assign people of different racial groups to differential and inequitable social spaces (Lipsitz, 2011).

The structures that produce unearned benefits of Whiteness, themselves grounded in hypodescent, and are responsible for pervasive and egregious forms of structural oppression against people of color, also benefit monoracial groups of color ("monoracial privilege") (Nadal et al., 2011, p. 43). Though these 
groups do not experience anything near the advantages of Whites, they have many cultural, social, economic, political outlets, and resources (Daniel et al., 2014), which may make it difficult for them to recognize their own monoracial privilege and biases. Whether intentional or unintentional, their own discriminatory attitudes and practices form part of what Johnston and Nadal referred to as "monoracism" (Johnston \& Nadal, 2010, p. 125).

Although monoraciality and hypodescent go hand in hand, they are not necessarily synonymous. The impetus behind support of monoraciality and, by extension, hypodescent among Whites differs considerably from that of communities of color. Whites historically formulated hypodescent to sustain monoracial imperatives based on the dichotomous and hierarchical ranking of racial (and cultural) differences in support of White racial exclusivity. But the unintended consequences of hypodescent and monoraciality for groups of color, especially for Blacks, was that exclusionary boundaries also helped forge and legitimate their monoracial group identities.

According to Jones (1994), the possessive investment of communities of color in hypodescent and monoraciality is grounded in the belief these are necessary for maintaining community and solidarity in the struggle against inequities perpetuated by White racism, oppression, and privilege. Communities of color thus uphold monoraciality and the accompanying dichotomization of racial differences by rearticulating (Omi \& Winant, 2014, p. 164) rather than by reproducing hypodescent. This process involves the repetition of hypodescent in support of racial difference without hierarchy, that is, difference based on equality. Notwithstanding this critical distinction, however, the outcome in both cases is the same: individuals reinforce, if only unwittingly, racial designations as if they were mutually exclusive and singular categories of experience as well as objective phenomena with an independent existence.

\section{The Postcivil Rights Era: Multiracial Identities and Mixed-Race Experiences}

The African-American civil rights movement helped dismantle Jim Crow segregation and achieved the implementation of legislation in the 1950s and 1960s that dissolved legal racial discrimination and inequality. The landmark 1967 Loving $v$. Virginia decision, which overturned statutes in the sixteen states prohibiting racial intermarriage, was a concomitant outcome of these gains. Comparatively more fluid social relations in the postcivil rights era led to the growth in the number of interracial marriages and in the numbers of multiracial offspring from these unions. Legalized marriages as consensual relationships include an element of choice, unlike coercive unions of the past under colonial domination; military occupation; and, particularly, slavery. Moreover, marriage confers equal legal status on both parties and, by extension, equal legitimacy on both parents' identities.

Yet even with the removal of legal restrictions on interracial marriage, there was no immediate social challenge to hypodescent or to the monoracial imperative in terms of racial categories and identification (Roberts, 1994). It was not until the late 1970s and early 1980s that many interracial couples, particularly individuals in Black-White relationships, began to counter norms by socializing their children to embrace multiracial identities. They also formed educational and support organizations addressing the concerns of interracial families and multiracial people, particularly their marginalization and frequently erasure and pathologization (DaCosta, 2007; Daniel, 2001; Williams, 2008, 2017).

Some of the celebratory and, at times, overenthusiastic images seeking to address and remedy these attitudes, including those in the mainstream media and popular culture, have understandably been criticized for espousing a naïve egalitarianism reinforcing and perpetuating the notion that interracial marriages would lead to a more tolerant society (Childs, 2005, 2009; Rodriguez-Garcia et al., 2016). There were also imaginings that multiracials are automatically imbued with special temperamental qualities, which make them ideally suited as the solution to racism and racial 
inequality (Daniel et al., 2014). Notwithstanding caveats, these images have been important in terms of valorizing interracial relationships and multiracial experiences.

Post-Loving multiracial identities include "first-generation" offspring of interracial marriages in which both parents are socially designated and self-identified as monoracial regardless of their multiple racial backgrounds. These identities are also exhibited by "multigenerational" individuals with two biracial-identified parents; or by those with one biracial-identified and one monoracialidentified parent. The multigeneration identity is also displayed by individuals who have parents, or even generations of ancestors, socially designated as monoracial despite multiple racial backgrounds (Daniel, 2001).

Data indicate multiracial identities are influenced but not necessarily determined by individuals' phenotypical traits; family, peers, and society also have a significant impact (Bradshaw, 1992; Hall, 1992; Pauker et al., 2018; Root, 1990; Sims, 2016; Wallace, 2001; Wijeyesinghe, 2012). These data also show multiracial-identified individuals have multiple and shifting contextual and temporal points of reference rather than fixed or predictable parameters (Brunsma et al., 2013; Pauker et al., 2018; Pew Research Center, 2015; Poston, 1990; Root, 1992).

Notwithstanding illusive parameters, however, multiracial identities manifest themselves between the boundaries of monoracial groups, extending outward from liminal locations contingent upon an individual's orientation toward the groups that compose their background. A shared liminality based on identification with more than one racial background is, in fact, an integral, fundamental part of the self-conception of multiracial-identified individuals and a defining component of all mixed-race experiences (Anzaldúa, 1987; Castañeda-Liles, 2012; Cornell \& Hartmann, 1998; DaCosta, 2007; Daniel, 2001, Daniel, 2021; Field, 1996; Renn, 2004; Rockquemore \& Brunsma, 2002; Wallace, 2001; Wilton et al., 2013).

Zarine Rocha (2016) contended multiracial identities indicate strategic choices individuals operationalize calling into question and refusing to fit into traditional racial categories buttressed by and sustaining monoracialism. Although multiracial identities contest the mutually exclusive nature of racial boundaries, they do not dismiss monoracial forms of identification in and of themselves as illegitimate. They rather, question the external ascription of monoracial identifications as the norm against which all other forms of identification are deemed unacceptable. Depending on the circumstances, individuals may manifest different affinities or resonances with specific components of their backgrounds, as well as with the groups that embody them. In direct contradiction to hypodescent, they do not privilege any one background over the other in terms of intrinsic value and worth. These identities challenge the hierarchical valuation of racial differences and their inequitable power relations (Brown, 1990; Daniel, 2001; Daniel, 2021; Gaither, 2015; Korgen, 1998; Wardle, 1987).

Multiracial identities therefore interrogate the monoracial comportment line supporting European Americans' investment in Whiteness with its associated cultural, social, economic, political, and other advantages. These identities also call into question the equally profound investment communities of color have in preserving monoracial identities in response to those inequities. They overlook or outright reject the possibility of a multiracial identity formulated on nonhierarchical or antiracist, that is, critical, premises. Consequently, multiracial identities are not regarded as resistance to the core and foundational tenets of U.S. racial commonsense. Instead, they are often conflated with the desire to evade racial stigma and achieve social advantages closer to Whites in the racial hierarchy (Elam, 2011; Sexton, 2008; Spencer, 1997; Spencer, 1999). There is no substantive data to support the notion multiracial identity formations actually aspire to Whiteness. Yet some individuals may identify as multiracial in order to achieve White adjacency. Furthermore, multiracial identities, like all racial identities, continue to function under the constrictions of the U.S. racial order that privilege individuals 
who more closely approximate European Americans in terms of physical appearance as well as assumed behavioral and attitudinal characteristics. ${ }^{4}$

Numerous studies indicate multiracials display a critical awareness of these inequities. This can range from informal criticism of everyday manifestations of racist power dynamics to formal engagement in antiracist work, which centers the role multiracials can perform in the struggle for racial justice (Buggs, 2017; Daniel, 2001, 2014, Daniel, 2021; Harris, 2019; Jackson, 2012; Renn, 2004; Rockquemore \& Brunsma, 2002; Wallace, 2001; Wijeyesinghe, 2012). This is not to suggest multiracial identities are inherently the solution, in and of themselves, to racism and racial inequality (Daniel, 2001, 2006; Mahtani, 2014; Warren \& Sue, 2011). Rather, this posits multiraciality - and more broadly, "betwixt and between" conceptual stances - as a template for engaging in a social praxis that critiques racial essentialism and racial hierarchy and supports more inclusive collective subjectivities across the racial spectrum, including multiracials. This can help avoid defensive-aggressive polarizations bound in an irresolvable stalemate between inclusion and exclusion, which may be counterproductive in terms of collaborating on other issue-based concerns. These stances therefore offer a basis from which to advance thinking and policies that seek to ameliorate racism, racial inequalities, and foster social justice (Daniel et al., 2014; Daniel, 2021; Jolivette, 2011; Williams, 2017; Williams et al., 1996).

\section{Betwixt and Between: From Marginality to Liminality in the Social Sciences}

In the 1980s and 1990s, psychologists and social psychologists conducted the majority of social science research on mixed-race identities and multiracial experiences. Some anthropologists and scholars in social work also made inroads (Daniel et al., 2014; Root, 1992). Sociology was less visible, aside from the work of a few individuals. Niemonen examined all racial and ethnic relations articles (677 articles in total) published over a twenty-seven-year period from January 1969 through December 1995 in American Journal of Sociology, American Sociological Review, Social Forces, and Social Problems. He found the articles borrow from, take for granted, accept, and indeed reify U.S. racial commonsense or U.S. Census definitions of race and ethnicity as opposed to critically evaluating or critiquing them (Niemonen, 1997). An interrogation of these categories would be central to any discussion of multiraciality and mixed-race experiences.

Daniel found a similar pattern in his examination of Sociological Abstracts to determine the presence or absence of discussions of multiraciality and mixed-race experiences in U.S. journal articles. He discerned that articles investigating the topic of race from 1952 to 1992, the year of publication of Root's (1992) ground-breaking Racially Mixed People in America, indicated limited attention to the topic of multiraciality and mixed-race experiences. ${ }^{5}$ Between 1988 and 1992, there

\footnotetext{
${ }^{4}$ See, for example, Bonilla-Silva, 2003; Allen et al., 2000; Hagiwara et al., 2012; Hughes and Hertel, 1990; Keith \& Herring, 1991; Monk, 2014; Rondilla \& Spickard, 2007; Viglione et al., 2011; Wade et al., 2004; Weaver, 2015.

${ }^{5}$ The search terms "race AND (United States) resulted in 3837 abstracts; "race AND (United States) AND (mixed race)" yielded 55 relevant results; "race AND (United States) AND (multiracial) provided 2 relevant results both of which were duplicates of the previous search under mixed race. Some articles examined interracial marriage (23); others examined multiraciality, mixed-race offspring, and mixed-races experiences (33), many of them on Hawai'i (8), a state that has historically had a high percentage of interracial marriages and multiracial offspring. Interestingly, there were several articles specifically on communities commonly referred to as "triracial isolates" (7). These communities are composed of individuals of varying degrees of European, African, and Native American ancestry, who for several generations have asserted identities that resist the U.S. monoracial imperative (see Daniel 2001, 2006). However, of approximately 396 books published between 1989-2005 on the topic of multiracial identities, mixed race experiences, and related topics in terms of U.S. racial formation only 10 were written by sociologists. An examination of 40 standard U.S. sociology undergraduate textbooks published in the 1990s reveals a noticeable absence of the topic.
} 
was a noticeable increase in the number of articles, with a dramatic increase from 1992 to $2013 .^{6}$ In 1995, and particularly beginning in 1998, papers, roundtables, sections, and regular sessions on multiracial identity became a recurring component of American Sociological Association annual meetings. This is a significant development. One cannot, however, consider it emblematic of exponential or dramatic growth. ${ }^{7}$

That said, an important advance in research on multiraciality was to reevaluate the concept of marginality, which had focused on the psychological dysfunction purportedly originating in mixed-race experiences (McKibben, 2018). According to this line of reasoning, marginality was necessarily pathological. Individuals ostensibly stood on the margin of two racial or cultural and often mutually exclusive and hostile worlds, not fully a member of either. This caused life-long personal conflict characterized by divided loyalties, ambivalence, and hypersensitivity (Caballero \& Aspinall, 2015; Smith, 1986; Stonequist, 1937).

Admittedly, such theories emerged when the U.S. was significantly more hostile to the affirmation of multiracial identities, thinking that fixated on the supposed genetic inferiority of multiracials and was supported by scientific racism and theories of hybrid degeneracy (Caballero \& Aspinall, 2015). By the end of the first half of the twentieth century, these theories had largely been substituted with theories of marginality. These focused on the psychological dysfunction purportedly originating in mixed-race experiences rather than on social forces that made psychological functioning difficult for multiracials. They therefore supported the prevailing ideology that prohibited or discouraged miscegenation seeking to preserve White racial purity and dominance (Daniel, 2001, 2006).

Theories of "negative" marginality emphasizing pathology, especially the work of sociologist Stonequist (1901-1979), overshadowed the nuances of sociologist Park's (1864-1944) original "marginal man" thesis in the 1920s (Caballero \& Aspinall, 2015; Daniel, 2001, 2006; Park, 1928; Park in Stonequist, 1937). Park did not dismiss the challenges, psychological ambivalence, and conflict that could accompany marginality. However, he believed "positive" marginality could also imbue individuals with a broader vision and wider-ranging sympathies (as cited in Stonequist, 1937, p. xiii-xviii), which might enable them to help facilitate mutual understanding between individuals from different groups (Goldberg, 2012; Marotta, 2007; Smith, 1986). Notwithstanding Park's conceptualization, which was elaborated on and refined by subsequent sociologists (Antonovsky, 1956; Gist \& Dworkin, 1972; Goldberg, 1941; Green, 1947; Kerchkhoff \& McCormick, 1955; Wright $\&$ Wright, 1972), the received wisdom reified theories of negative marginality.

In addition, prior to the 1980 s, the identity formation of children of interracial marriages had received limited attention from educators, researchers, social scientists, and mental health professionals. The extant research was outdated, contradictory, or based on small-scale case studies of children experiencing "problems" with identity and referred for psychological counseling (Hall, 1992; TaylorGibbs, 1987; Taylor-Gibbs \& Hines, 1992). Rather than positing these identity struggles as a sign of alienation in response to the perceived illogics of hypodescent and monoraciality (Spickard, 1992), they were deemed symptomatic of anomie or temporary deviations in an otherwise functioning racial order (Horton, 1966). In terms of children with Black and White parentage, professionals stressed the

\footnotetext{
${ }^{6}$ Using the search terms "race AND (United States) AND (mixed race)," Daniel found 100 relevant results; using "race AND (United States) AND (multiracial) he found 65 relevant articles most of them duplicates of titles found under mixed race.

7 ASA Annual Meetings https://www.asanet.org/news-events/meetings/previous-annual-meetings. Yet Daniel's observations of public behavior found there was still considerable controversy, conflict, and even acrimony surrounding multiracial identity displayed by attendees at sessions and panels of the American Sociological Association and Pacific Sociological Association annual meetings well into the late 1990s and early 2000s.
} 
importance of learning to cope as African Americans because society would view them as such. Their mental health was assessed in terms of how successfully or unsuccessfully they achieved a Black identity (Hall, 1992; McKibben, 2018; Taylor-Gibbs, 1987; Taylor-Gibbs \& Hines, 1992; Tizard \& Phoenix, 1994).

\section{The Multiracial Movement and Positive Marginality}

By the 1980s, a new wave of research finally put to rest theories of negative marginality. These and subsequent studies indicated multiracials, generally speaking, are just as well-adjusted as monoracials, notwithstanding the various challenges they may encounter in forming positive identities (Daniel, 2001; Goldberg, 2012; Poston, 1990; Root, 1990, 1992; Wijeyesinghe, 2012; Williams-León \& Nakashima, 2001). The concept of positive marginality (or liminality), that is, the sense of being "betwixt and between," (Turner, 1967, p. 97), in turn, gained greater acceptance among mental health professionals (Hall, 1992).

That said, there was limited information on the actual size of the multiracial population, which was rarely visible in statistical series and reports produced by state and federal agencies. This may have, of itself, dampened scholarly interest in the population. Yet in the late 1980s and early 1990s demographers increasingly began to grapple with the statistical implications of this population as interracial couples and multiracial-identified individuals began lobbying the racial state to change procedures in collecting official data on race and ethnicity - particularly on the 1990 census - so that multiracial-identifying individuals could be enumerated. The subsequent burst in sociological and other scholarship seeking to capture this population can be attributed, in part, to the publication of findings from the 2000 and 2010 censuses, which, for the first time, allowed multiracials to check more than one box on the census race question (Chew et al., 1989; DaCosta, 2007; Daniel, 2001, 2006; Lee, 1993; Waters, 2000; Williams, 2008, 2017). ${ }^{8}$

The increased saliency of "multiracial" as a self-identifier and category came about through the growth in the population of multiracials sometimes referred to as the "Loving Generation" (Daniel et al., 2014, p. 17). These individuals were born in the late 1960s and early 1970s following the Loving $v$. Virginia decision although some definitions extend the parameters into the early 1980s. Prewitt (2013) argued the multiracial movement gained increased momentum in the 1980s and 1990s in concert with growing support of multiculturalism. This framework espoused an egalitarian ethos valuing racial and cultural diversity, which was stimulated by the immigrant wave of the period. Indeed, Prewitt maintains "It was in the context of immigration-driven multiculturalism that the movement to recognize multiraciality in the census gained political traction" (Prewitt, 2013, p. 132).

During the height of the intense activity in the late 1990s surrounding the census debate, the multiracial movement was composed of 30 grassroots organizations with about 3,500 active participants (Williams, 2008, 2017). ${ }^{9}$ Yet activism surrounding multiracial identity politics was

\footnotetext{
${ }^{8}$ Activists were unsuccessful in bringing about changes on the 1990 census. Yet their efforts came to fruition with the 2000 census, which, for the first time, allowed multiracial-identified individuals to check more than one box on the census race question. Multiracials (or the "more than more race" population) totaled 7 million or 2.4 percent of the population. Based on 2010 census data their numbers increased to 9 million people — or 2.9 percent of the population. Although multiracials still make up only a fraction of the total population, this is a growth rate of about 32 percent since 2000. The publication of these findings may help explain the subsequent burst in sociological and other scholarship compared to the previous paucity of analyses attributable to the absence of these data.

${ }^{9}$ Its comparatively small size notwithstanding, political scientist Williams (2017) contended the multiracial movement set in motion a process that has both amplified and been amplified by broader structural and cultural changes in how people in the United States perceive race. Indeed, the size of active membership is not the final determinant of what constitutes a social movement. Tilly (2004) and Tarrow (2011) defined a social movement as sustained interaction
} 
initially considered a marginal racial project. At best, the multiracial phenomenon was considered symptomatic of largely isolated and ephemeral psychological concerns with personal identity (Daniel et al., 2014; McKibben, 2018). It was located outside the normative terrain of the racial state, the public imagination, as well as that of most sociologists (Daniel, 2001, 2006; Williams, 2008, 2017). Indeed, the topic was not discussed in the second edition of the canonical Racial Formation in the United States by sociologists Omi and Winant (1994). This new edition encompassed changes in U.S. racial formations since its initial publication in 1986. Yet it failed to include a discussion of the census debate that was well under way. ${ }^{10}$ The fact that sociologists failed to see what was there to be seen is a case study where the absence of evidence, or negative evidence, constitutes the evidence of absence. A meditation on what was not there in sociological analyses is thus part of a meaningful measurement of sociologists' monoracial subjectivity and standpoint with respect to multiracial identities and mixed-race experiences in the late 1980s and early 1990s (Kinefuchi \& Orbe, 2008; Thompson \& Scurich, 2018).

\section{The Power-Conflict and Order-Functional Paradigms}

Since the 1990s, the number of articles, book chapters, and monographs published on multiracial identities and mixed-race experiences has grown exponentially. Even a partial list would hardly do justice to the volume of publications. By 2004, scholarly articles had appeared in all the flagship and high-impact journals in sociology, psychology, anthropology, history, literature, as well as in other disciplines and fields of study (Daniel et al., 2014). Sociologists have made a valuable contribution to this research. Yet the multiracial phenomenon has been largely studied in terms of individual identity. There has been less engagement with analyses of broader structural concerns, social behavior, and social relations particularly collective identity, agency, and political action regarding the order-functional and powerconflict paradigms.

By virtue of their hybridity and liminal positionality, multiracial identities raise questions about the theoretical assumptions of these two paradigms of sociological analysis. On the one hand, multiracial identities challenge the power-conflict paradigm that essentially reinforces the notion multiracials will display single-racial identities of color. Monoracial identities are not only deemed normative but also a means of maintaining community and solidarity in the struggle against inequities perpetuated by White racism, oppression, and privilege. On the other hand, multiracial identities cast doubt on the order-functionalist paradigm, which portends the eventual racial absorption of multiracials into the larger racial (and ostensibly White) mainstream (or at least are no longer considered racialized "others") due to increased interracial marriage (Alba, 2009, 2020; BonillaSilva, 2003; Gans, 2012; Gordon, 1964; King-O’Riain, 2006; Lee \& Bean, 2010; Newman, 2020; Qian \& Lichter, 2007).

Individuals with a more European American appearance among White/Asian American, White/Latinas/os, or White/Native American multiracials, have greater White adjacency in the racial order and are more easily able to achieve monoracial White identification (Bonilla-Silva, 2003; Daniel, 2001, 2006; Mass, 1992). Research indicates this option is not necessarily available for multiracials with African ancestry because it is precluded by the one-drop rule, which still strongly influences identity formation through external imposition as well as self-ascription (Khanna,

\footnotetext{
with elites, opponents, and authorities by ordinary people through various contentious displays, performances, and campaigns making collective claims.

${ }^{10}$ Omi (1997) published a referred journal article that contains a brief discussion of multiraciality and the census debate. The $3^{\text {rd }}$ edition of Racial Formation in the United States, published in 2014, devotes considerable attention to the multiracial phenomenon.
} 
2010, 2011; Rockquemore \& Brunsma, 2002; Roth, 2005). While the affirmation and acceptance of a multiracial identity partially negates the one-drop rule, to accomplish racial integration as White would require a complete societal repudiation of the rule (Daniel, 2006; Hoskins, 2011; Lee \& Bean, 2010; Strmic-Pawl, 2016).

Bratter's study (2007) of the intergenerational transfer of multiracial identities revealed robust evidence of the continuing impact of rigid racial categories and boundaries in terms of Black/White multiracials. These can be measured when multiracial-identified parents of African descent did not consistently transfer their identification to their offspring. Bratter discovered many individuals formed families with people of similar racial background (e.g., White/Black mother and Black father) and identified their children according to normative one-drop rule monoracial expectations (i.e., Black). Lee and Bean (2010) reached similar conclusions. Like Bratter, they attribute this retention to the enduring, if attenuated, influence of the one-drop rule.

Other analyses indicate the one-drop rule has comparatively less impact on identity formation among multiracials of African descent. Some research indicates Black/White young people who phenotypically more closely approximate European Americans often have access to a White racial identity. This identity can result from the preponderance of Whites in their social milieu and/or relative lack of contact with family members and other Black individuals. Moreover, their identity is validated through social interaction, particularly with White peers (Khanna, 2010, 2011; Korgen, 1998; Renn, 2004, 2008; Rockquemore \& Brunsma, 2002; Rockquemore \& Laszloffy, 2005).

Lee and Bean (2010), as well as Townsend et al. (2012), noted identifications can differ depending on the various backgrounds and identity options available. For example, Townsend et al. (2012) discovered Asian American/White individuals were more likely than Black/White or Latina/o/White individuals to identify as multiracial. Lee and Bean found multiracials of White/Asian American or White/Latina/o backgrounds have greater flexibility institutionally or through social interaction to identify as Asian American or Latina/o, respectively, as well as White or multiracial. Lee and Bean (2010), Hoskins (2011), and Miyawaki (2016), indicated that among many White/Asian American individuals there is nevertheless a trend heavily tilted in the direction of Whiteness in terms of marriage partners and progeny (Pew, 2015).

Jiménez's (2004) research also illustrated Latina/o/White multiracials and their offspring display considerable flexibility and variation with their identities, including the option to identify as Latina/o, multiracial, and White. Many are perceived as White, and for some, their Latina/o identity is largely "symbolic" without much impact on their daily lives (Miyawaki, 2016). Whereas Whiteness is possible for Latina/o/Whites, Hoskins (2011) and Romo (2011) contend "dual-minorities" (e.g., Latina/o/Blacks, Latina/o/Asian Americans, Black/Asian Americans, etc.) do not necessarily have this option; their background and physical appearance typically mark them as non White whether they identify as multiracial or with one or both of their backgrounds of color.

Song's (2017) analysis of multiracial parents in Great Britain, that is, multiracials who marry other multiracials, provided an interesting counter. Her data indicated a strong retention of multiracial identities among the majority of her respondents and their offspring. Song recruited 62 multiracial parents, 37 women and 25 men, with one White and one nonWhite parent. Most (54) were first-generation individuals whose backgrounds were composed of three groups reflecting the most common multiracial combinations in Britain: 32 Black/White, 19 South Asian/White, and 11 East Asian/White couples. Most multiracial parents identified their children on official forms as "mixed" (40), followed by White (14). None identified them as a monoracial "minority" (or group of color).

Song cautioned against assuming identities selected on forms speak for themselves. Choosing a White identity, for example, does not necessarily reflect a desire to be White. Some parents identified their children as White due to their limited personal contact with their minority parent. 
Others selected White due to the generational distance from their minority ancestor. Indeed, the few Black/White participants who identified their children as White did so because of this generational distance, as well as their children's White appearance, which they understood as affording them status and protection. Others identified their children as mixed race even when they appeared White.

A shared liminality grounded in identification with more than one racial background can become an integral component of multiracial self-conception. Yet Song found no unifying experience of multiracials in the "mixed" category. Of the 62 participants, 34 identified with multiracials while 28 felt no commonality. Black/White multiracials displayed a stronger identification with other multiracials than did South Asian/White and East Asian/White respondents (Song, 2017). Larger samples would be needed to determine the relevance of these data in terms of their wider-ranging significance in Great Britain, and to what extent this pattern might be replicated in the United States, particularly in terms of a multiracial group or collective subjectivity.

\section{Conclusions: The Future of a Multiracial Collective Subjectivity}

Some insight into group identity appears in a Pew (2015) Research report "Multiracial in America" from an online survey of a nationally representative sample of 1,555 multiracials ages 18 and older. For comparative purposes, an additional 1,495 adults from the general public were surveyed. These data indicate multiracials variously experience the boundaries of their individual identities as "thick" (comprehensive) or "thin" (less comprehensive) and the centers as "soft" (more diffuse) or "hard" (less diffuse). The boundaries and centers of a multiracial collective subjectivity are currently much closer, respectively, to the thin and soft end of the spectrum.

Notwithstanding an embryonic sense of groupness among multiracials, multiracial designators currently function comparatively more as individual rather than as group identifiers, and are porous, multiple, and overlapping (Castañeda-Liles, 2012; Daniel, 2001; Johnston-Guerrero \& Ford, 2015; Newman \& Daniel, 2015; Pew, 2015; Spickard, 2016; Thornton, 1992). This could change if identities gain sufficient force to organize social and cultural life around a sense of groupness (Cornell \& Hartman, 1998; Daniel, 2001). Indeed, some basic ingredients supporting a sense of groupness are apparent in the numerous social spaces that have emerged speaking to collective multiracial concerns. These include websites, social media, student groups and college courses, support and educational organizations, socials, festivals, and conferences (Daniel, 2001, 2006, 2021; Daniel et al., 2014; Jackson, 2012; Jones, 2011).

Yet there may always be an intrinsic permeability to any sense of groupness among multiracials. To some extent this can be attributed to the fact that multiracial identities are still an emerging phenomenon. They have historically suffered constraints prohibiting their development. They are also composed of myriad backgrounds and experiences, which are themselves multidimensional. Indeed, the specific racial components of individuals' backgrounds matter in terms of their sense of groupness, as survey research suggests there is an uneven degree to which subpopulations of multiracials of similar backgrounds identify with a broader multiracial collective subjectivity. Subgroup differences may impede the development of the sense of linked fate and shared experience uniting many Blacks and other groups of color. The feeling that one's individual fate is linked to the overall well-being of one's racial group would be a central component to solidifying any sense of groupness based on multiracial identities (Pew, 2015). Yet Song's research indicated the absence of a sense of groupness among multiracials does not preclude the intergenerational transferal or longevity of individual multiracial identities.

Despite the growing numbers and visibility of multiracial-identified individuals, as well as changes in data collection that now include them, the needle appears to be moving more slowly in 
terms of societal norms and racial commonsense (Alpert, 2013; Farley, 2001; Masouka, 2017; Newman, 2020). Yet the multiracial phenomenon is still a strong indication that sociologists need to reexamine the theoretical foundations of the sociology of race relations (Goldberg, 2012; Song, 2017). Both the power-conflict and order-functional paradigms are refracted through a monoracial lens informed by hypodescent that ignores, if not dismisses, any longevity to individual or collective multiracial identities and any societal scaffolding upon which they might take root.

\section{References}

Alba, R. (2009). Blurring of the color line: The new chance for a more integrated America. Harvard University Press.

Alba, R. (2020). The great demographic illusion: Majority, minority, and the expanding American mainstream. Princeton University Press.

Alcoff, L. M. (2006). Visible identities: Race, gender, and the self. Oxford University Press.

Allen, W., Telles, E. E., \& Hunter, M. L. (2000). Skin color, income, and education: A comparison of African Americans and Mexican Americans. National Journal of Sociology, 12(1), 129180.

Alpert, E. (2013, June 12). More Americans consider themselves multiracial. LA Times. https://www.latimes.com/local/la-xpm-2013-jun-12-la-me-multiracial-growth-20130613story.html

American Sociological Association. ASA Annual Meetings. https://www.asanet.org/newsevents/meetings/previous-annual-meetings

Antonovsky, A. (1956). Toward a refinement of the 'marginal man' concept. Social Forces, 35(1), 57-62. https://doi.org/10.2307/2573115

Anzaldúa, G. (1987). Borderlands/La Frontera: The New Mestiza. Aunt Lute Books.

Armstrong, J. (2019). "The Reward was Worth the Sacrifice": How Membership in Black Greek Letter Fraternities (BGLFs) Redefines Black Men's College Experiences. American Journal of Qualitative Research, 3(1), 1-19. https://doi.org/10.29333/ajqr/5808

Blauner, R. (1972). Racial oppression in America. Harper and Row.

Bonilla-Silva, E. (2003). Racism without racists: Color-Blind racism and the persistence of racial inequality in the United States (5th ed.). Rowman \& Littlefield.

Bradshaw, C. (1992). Beauty and the beast. In M. P. P. Root (Ed.), Racially mixed people in America (pp. 77-90). Sage Publications.

Bratter, J. (2007). Will 'multiracial' survive to the next generation?: The racial classification of children of multiracial parents. Social Forces, 86(2), 821-849. https://doi.org/10.1093/sf/86.2.821

Brown, P. (1990). Biracial identity and social marginality. Child Adolescent Social Work, 7(4), 319-37. https://doi.org/10.1007/BF00757029

Brunsma, D., Delgado, D., \& Rockquemore, K. (2013). Liminality in the multiracial experience: Towards a concept of identity matrix. Identities, 20(5), 481-502. https://doi.org/10.1080/1070289X.2013.827576

Buggs, S. (2017). Dating in the time of \#BlackLivesMatter: Exploring mixed-race women's discourses of race and racism. Sociology of Race \& Ethnicity, 3(4), 538-551. https://doi.org/10.1177/2332649217702658

Caballero, C., \& Aspinall, P. J. (2015). Mixed race in Britain in the Twentieth Century [Introduction]. Palgrave Macmillan. 
Castañeda-Liles, J. M. (2012). The multiracial reference group orientation scale (MRGOS): A new scale for use with mixed race populations (Publication No. 3545113) [Doctoral Dissertation, University of California]. ProQuest Dissertations Publishing.

Cheeseboro, A. Q. (1999). Conflict and continuity: E. Franklin Frazier, Oliver C. Cox, and the Chicago School of Sociology. Journal of the Illinois State Historical Society, 92(2), 50172. https://www.jstor.org/stable/40193213

Chew, K. S., Eggebeen, D. J., \& Uhlenberg, P. R. (1989). American children in multiracial households. Sociological Perspectives, 32(1), 56-85. https://doi.org/10.2307/1389008

Childs, E. C. (2005). Navigating interracial borders: Black-White couples and their social worlds. Rutgers University Press.

Childs, E. C. (2009). Fade to Black and White: Interracial images in popular culture. Rowan \& Littlefield.

Cornell, S. \& Hartmann, D. (1998). Ethnicity and race: Making identities in a changing world. Pine Forge Press.

DaCosta, K. M. (2007). Making multiracials: State, family, and market in the redrawing of the color Line. Stanford University Press.

Daniel, G. R. (2001). More than Black? Multiracial identity and the new racial order. Temple University Press.

Daniel, G. R. (2006). Race and multiraciality in Brazil and the United State: Converging paths? Penn State University Press.

Daniel, G. R. (2021). Foreword. In M. P. Johnston-Guerrero \& C. L. Wijeyesinghe (Eds). Multiracial Experiences in Higher Education: Contesting Knowledge, Honoring Voice and Innovating Practice, (pp. ix-xix). Stylus Publishing.

Daniel, G. R., Kina, L., Dariotis, W. M., \& Fojas, C. (2014). Emerging paradigms in critical mixed race studies. Journal of Critical Mixed Race Studies, 1(1), 6-65. https://escholarship.org/uc/item/2db5652b

Davis, F. J. (2001). Who Is Black? One nation's definition. Pennsylvania State University.

Douglas, M. (1966). Purity and danger: An analysis of the concepts of pollution and taboo. Routledge \& Kegan Paul Ltd.

Elam, M. (2011). The Souls of mixed folk: Race, politics, and aesthetics in the new millennium. Stanford University Press.

Enstad, N. (1999). Ladies of labor, girls of adventure: Working women, popular culture, and labor politics at the turn of the twentieth Century. Columbia University Press.

Farley, R. (2001). Identifying with multiple races: A social movement that succeeded but failed? [PSC Research Report, no. 01-491]. https://www.psc.isr.umich.edu/pubs/abs/1315

Feagin, J., \& Feagin, C. B. (2012). Racial and ethnic relations (9th ed.). Pearson Education, Inc.

Field, L. (1996). Piecing together the puzzle: Self-Concept and group identity in biracial Black/White youth. In M. P. P. Root (Ed.), The multiracial experience: Racial borders as the new frontier (pp. 211-226). Sage Publications.

Forbes, J. D. (1988). Black Africans and Native Americans: Color, race, and caste in the evolution of Red-Black peoples. Blackwell.

Gaither, S. (2015). Multiracial research and identity explorations. Current directions in psychological science, 24(2), 114-119. https://doi.org/10.1177/0963721414558115

Gans, H. (2012). 'Whitening' and the changing American racial hierarchy. Du Bois Review, 9(2), 267-279. https://doi.org/10.1017/S1742058X12000288

Gines, K. T. (2013). Introduction: Critical philosophy of race beyond the Black/White Binary. Critical Philosophy of Race 1(1), 28-37. https://doi.org/10.5325/critphilrace.1.1.0028 
Gist, N. P., \& Dworkin, A. G. (Eds.). (1972). The blending of races: Marginality and identity in world perspective. Wiley-Interscience.

Goldberg, C. A. (2012). Robert Park's marginal man: The career of a concept in American sociology. Laboratorium, 4(2), 199-217. https://www.soclabo.org/index.php/laboratorium/article/view/4

Goldberg, M. M. (1941). A qualification of the marginal man theory. American Sociological Review, 6, 52-58. http://www.jstor.org/stable/2086343

Gordon, M. (1964). Assimilation in American life. Oxford University Press.

Green, A. W. (1947). A Re-examination of the marginal man concept. Social Forces, 26, 167-71. https://doi.org/10.2307/2571773

Guevarra, R. (2012). Becoming Mexipino: Multiethnic identities and communities in San Diego. Rutgers University Press.

Gurer, C. (2019). Refugee Perspectives on Integration in Germany. American Journal of Qualitative Research, 3(2), 52-70. https://doi.org/10.29333/ajqr/6433

Hagiwara, N., Kashy, D. A., \& Cesario, J. (2012). The independent effects of skin tone and facial features on Whites' affective reactions to Blacks. Journal of Experimental Social Psychology, 48(4), 892-98.

Hall, C. C. I. (1992). Please choose one: Ethnic identity choices for biracial individuals. In M. P. P. Root (Ed.), Racially mixed people in America (pp. 250-264). Sage Publications.

Harris, J. C. (2019). Multiracial campus professionals' experiences with racial authenticity. Equity \& Excellence in Education, 52(1), 1-15. https://doi.org/10.1080/10665684.2019.1631232

Harris, M. (1964). Patterns of race in the Americas. Walker and Company.

Horton, J. (1966). Order and conflict theories of social problems as competing ideologies. American Journal of Sociology, 7(6), 701-713. https://doi.org/10.1086/224226

Hoskins, B. C. (2011). Asian American racial realities in Black and White. Lynne Rienner Publishers.

Hughes, M., \& Hertel, B. R. (1990). The significance of color remains: A study of life chances, mate selection, and ethnic consciousness among Black Americans. Social Forces, 68(4), 1105-1120.

Jackson, K. F. (2012). Living the multiracial experience: Shifting racial expressions, resisting race, and seeking community. Qualitative Social Work, 11(1), 42-60. https://doi.org/10.1177/1473325010375646

Jiménez, T. R. (2004). Negotiating ethnic boundaries multiethnic Mexican Americans and ethnic identity in the United States. Ethnicities, 4(1), 75-97. https://doi.org/10.1177/1468796804040329

Johnston-Guerrero, M., \& Ford, K. S. (2015). Draw your own box? Further complicating racial data for multiracial/two or more races college students. In R. T. Teranishi, B. M. D. Nguyen, C. M. Alcantar, \& W. R. Curammeng (Eds.), Measuring race: Why disaggregating data matters for addressing educational inequality (pp. 84-102). Teachers College Press.

Johnston, M. P., \& Nadal, K. L. (2010). Multiracial microaggressions: Exposing monoracism in everyday life and clinical practice. In D. W. Sue (Ed.), Microaggressions and marginality: Manifestation, dynamics, and impact (pp. 123-44). Wiley.

Jolivétte, A. J. (2011). Critical mixed-race studies: The intersections of identity and social justice. In K. O. Korgen, J. M. White, \& S. K. White (Eds.), Sociologists in action: Sociology, social change, and social Justice (pp. 24-28). Pine Forge Press.

Jones, J. A. (2011). Who are we? Producing group identity through everyday practices of conflict and discourse. Sociological Perspectives, 54(2), 139-162. https://doi.org/10.1525/sop.2011.54.2.139

Jones, R.S. (1994). The end of Africanity? The assault on Blackness. Western Journal of Black Studies, 18(4), 201-10. https://eric.ed.gov/?q=End+of+Africanity 
Jordan, W. D. (2014). Historical origins of the one-drop rule in the United States. Journal of Critical Mixed Race Studies, 1(1), 98-132. https://escholarship.org/uc/item/91g761b3

Keith, V. M., \& Herring, C. (1991). Skin tone and stratification in the Black community. American Journal of Sociology, 97(3), 760-778. https://doi.org/10.1086/229819

Kerckhoff, A. C., \& McCormick, T. C. (1955). Marginal status and marginal personality. Social Forces, 34(1), 48-55. https://doi.org/10.2307/2574259

Khanna, N. (2010). If you're half Black, you're just Black: Reflected appraisals and the persistence of the one-drop rule. The Sociological Quarterly, 51, 96-121. https://doi.org/10.1111/j.15338525.2009.01162.x

Khanna, N. (2011). Biracial in America: Forming and Performing Racial Identity. Lexington Books.

Kim, C. J. (1999). The racial triangulation of Asian Americans. Politics \& Society, 27(1), 105-138. https://doi.org/10.1177/0032329299027001005

Kinefuchi, E., \& Orbe, M. P. (2008). Situating oneself in a racialized world: Understanding student reactions to Crash through standpoint theory and context-positionality frames. Journal of International \& Intercultural Communication, $1(1), 70-90$. https://doi.org/10.1080/17513050701742909

King-O'Riain, R. C. (2006). Pure beauty: Judging race in Japanese American beauty pageants. University of Minnesota Press.

Korgen, K. (1998). From Black to biracial: Transforming identity among Americans. Praeger.

Ladner, J. (1973). Introduction. In J. Ladner (Ed.), The death of White sociology, (pp. xix-xxix). Vintage Books.

Lee, J., \& Bean, F. D. (2010). The diversity paradox: Immigration and the color line in twenty-first century America. Russell Sage Foundation.

Lee, S. M. (1993). Racial classifications in the U.S. Census. Ethnic and Racial studies, 16(1), 7594. https://doi.org/10.1080/01419870.1993.9993773

Leonard, K. I. (1992). Making ethnic choices: California's Punjabi Mexican Americans. Temple University Press.

Lipsitz, G. (1998). The possessive investment in Whiteness: How White people profit from identity politics. Temple University Press.

Lipsitz, G. (2011). How racism takes place. Temple University Press.

Loewen, J. W. (1971). The Mississippi Chinese: Between Black and White. Harvard University Press.

Mahtani, M. (2014). Mixed race amnesia: Resisting the romantization of multiraciality. UBC Press.

Marotta, V. P. (2007). Civilisation, culture, and the hybrid self in the work of Robert Ezra Park. Journal of Intercultural Studies, 27(4), 413-433. https://doi.org/10.1080/07256860600936911

Masouka, N. (2017). Multiracial identity and racial politics in the United States. Oxford University Press.

Mass, A. I. (1992). Interracial Japanese Americans: The best of both worlds or the end of the Japanese American community? In M. P. P. Root (Ed.), Racially Mixed People in America (pp. 265-211). Sage Publications.

McKee, J. B. (1993). Sociology and the race problem: The failure of a perspective. University of Illinois Press.

McKibben, M. L. (2018). Shades of gray: Writing the new multiracialism. University of Nebraska Press.

Miyawaki, H. M. (2016). Part-Latinos and racial reporting in the census: An issue of question format? Sociology of Race \& Ethnicity, 2(3), 289-306. https://doi.org/10.1177/2332649215613531 
Monk, E. (2014). Skin tone stratification among Black Americans, 2001-2003. Social Forces, 92(4), 1313-1337.

Murray, P. (1997). States' laws on race and color. University of Georgia Press.

Nadal, K. L., Wong, Y., Cargas, V., Wideman, M., \& Kolawole, A. (2011). Microaggressions and the multiracial experience. International Journal of Humanities \& Social Science 1(7), 3644. http://www.ijhssnet.com/journals/Vol._1_No._7_\%5BSpecial_Issue_June_2011\%5D/6.pdf

Nash, G. B. (2014). Red, white, and black: The peoples of early America (7th ed.). Pearson.

Newman, A. M. (2020). Revisiting the marginal man: Bridging immigration scholarship and mixed-race studies. Sociology of Race \& Ethnicity, 1-15. https://doi.org/10.1177/2332649220933302

Newman, A. M., \& Daniel, G. R. (2015). Colorblind ideology, multiculturalism, and collective identity formation among mixed race adolescents in Northern California. In C. Hudley (Ed.), Adolescent identity and schooling: Diverse perspectives (pp. 23-38). Routledge.

Niemonen, J. (1997). The race relations problematic in American sociology: A case study and critique. The American Sociologist, 28(1), 15-54. https://doi.org/10.1007/s12108-997-1025-0

O'Brien, E. (2008). The racial Middle: Latinos and Asian Americans living beyond the racial divide. NYU Press.

Omi, M. (1997). Racial identity and the state: The dilemmas of classification. Law \& Inequality: A Journal of Theory \& Practice, 15(1), 7-22. https://scholarship.law.umn.edu/lawineq/vol15/iss1/2

Omi, M., \& Winant, H. (1994). Racial Formation in the United States from the 1960s to the 1990s (2nd ed.). Routledge.

Omi, M., \& Winant, H. (2014). Racial Formation in the United States (3rd ed.). Routledge.

Park, R. E. (1928). Human migration and the marginal man. American Journal of Sociology, 33(6), 881-893. https://doi.org/10.1086/214592

Park, R. E. (1937). Introduction. In E. V. Stonequist (Ed.), The marginal man: A study in personality and culture conflict (pp. xiii-Xviii). Russell \& Russell.

Pauker, K., Meyers, C., Sanchez, D. T., Gaither, S. E., \& Young, D. M. (2018). A review of multiracial malleability: Identity, categorization, and shifting racial attitudes. Social \& Personality Psychology Compass, 12(6)1-15. https://doi.org/10.1111/spc3.12392

Perea, J. F. (1997). The Black/White binary paradigm of race: The normal science of American racial thought, California Law Review, 85(5), 127-172. https://doi.org/10.15779/Z38MF05

Pew Research Center. (2015, June 11). Multiracial in America: Proud, diverse, and growing in numbers. https://www.pewsocialtrends.org/2015/06/11/multiracial-in-america/

Poston, W. S. C. (1990). The biracial identity development model: A needed addition. Journal of Counseling \& Development, 69(2), 152-155. https://doi.org/10.1002/j.1556-6676.1990.tb01477.x

Prewitt, K. (2013). What is 'your' race?: The census and our flawed efforts to classify Americans.

Princeton University Press.

Qian, Z., \& Lichter, D. T. (2007). Social boundaries and marital assimilation: Interpreting trends in racial and ethnic intermarriage. American Sociological Review, 72(1), 68-94. https://doi.org/10.1177/000312240707200104

Renn, K. A. (2004). Mixed Race students in college: The ecology of race, identity, and community on campus. State University of New York Press.

Renn, K. A. (2008). Research on biracial and multiracial identity development: Overview and synthesis. New directions for Student Service. Special Issue: Biracial and Multiracial Students, 123 Autumn (Fall), 13-21. https://doi.org/10.1002/ss.282

Ringer, B. B. (1983). We the people and others: Duality and America's treatment of its racial minorities. Tavistock. 
Roberts, R. E. T. (1994). Black-White intermarriage in the United States. In W. R. Johnson \& M. D. Warren (Eds.), Inside the mixed marriage: Accounts of changing attitudes, patterns, and perceptions of cross-cultural and interracial marriages (pp. 25-79). University Press of America.

Rocha, Z. L. (2016). 'Mixed Race' identities in Asia and the Pacific: Experiences from Singapore and New Zealand. Routledge.

Rockquemore, K. A., \& Brunsma, D. L. (2002). Beyond Black: Biracial identity in America. Sage.

Rockquemore, K. A., \& Laszloffy, T. (2005). Raising biracial children. Altamira Press.

Rodríguez-García, D. (2015). Intermarriage and integration revisited: International experiences and cross-disciplinary approaches. The ANNALS of the American Academy of Political \& Social Science, 662(1), 8-36. https://doi.org/10.1177/0002716215601397

Rodríguez-García, D., Solana-Solana, M., \& Lubbers, M. J. (2016). Preference and prejudice: Does intermarriage erode negative ethno-racial attitudes between groups in Spain? Ethnicities, 16(4), 521-546. https://doi.org/10.1177/1468796816638404

Romo, R. (2011). Between Black and Brown: Blaxican (Black-Mexican) multiracial identity in California. Journal of Black Studies, 42(3), 402-426. https://doi.org/10.1177/0021934710376172

Rondilla, J. L., \& Spickard, P. (2007). Is lighter better: Skin-tone discrimination among Asian Americans. Rowman \& Littlefield Publishers.

Root, M. P. P. (1990). Resolving 'other' status: Identity development of biracial individuals. In L. S. Brown \& M. P. P. Root (Eds.), Complexity and diversity in feminist theory and therapy (pp. 185-205). Haworth Press.

Root, M. P. P. (Ed.). (1992). Racially mixed people in America. Sage Publications.

Roth, W. D. (2005). The end of the one-drop rule: Labeling of multiracial children in Black intermarriages. Sociological Forum, 20(1), 35-67. https://doi.org/10.1007/s11206-005-1897-0

Sexton, J. (2008). Amalgamation schemes: AntiBlackness and the critique of multiracialism. University of Minnesota Press.

Sims, J. P. (2016). Reevaluation of the influence of appearance and reflected appraisals for mixedrace identity: The Role of consistent and inconsistent racial perception. Sociology of Race \& Ethnicity, 2(4), 569-583. https://doi.org/10.1177/2332649216634740

Smith, A. (1986). Positive marginality: The experience of Black women leaders. In E. Seidman \& J. Rappaport (Eds.), Redefining social problems. Perspectives in social psychology. (pp. 101-113). Springer. https://doi.org/10.1007/978-1-4899-2236-6_7

Song, M. (2009). Is intermarriage a good indicator of integration? Journal of Ethnic \& Migration Studies, 35(2), 331-348. https://doi.org/10.1080/13691830802586476

Song, M. (2017). Multiracial parents: Mixed families, generational change, and the future of race. NYU Press.

Spencer, J. M. (1997). The new colored people: The mixed-race movement in America. NYU Press. Spencer, R. (1999). Spurious issues: Race and multiracial identity politics in the United States. Westview Press.

Spickard, P. (1989). Mixed blood: Intermarriage and ethnic identity in twentieth-century America. University of Wisconsin Press.

Spickard, P. (1992). The illogic of American racial categories. In M. P. P. Root (Ed.), Racially mixed people in America (pp. 333-341). Sage Publications.

Spickard, P. (2016). Race in mind: Critical essays [With J. Moniz \& I. Dineen-Wimberly]. Notre University of Notre Dame Press.

Steinberg, S. (2007). Race relations: A critique. Stanford University Press. 
Stonequist, E. V. (1937). The marginal man: A study in personality and culture conflict. Russell and Russell.

Strmic-Pawl, H. V. (2016). Multiracialism and its discontents: A comparative analysis of AsianWhite and Black-White multiracials. Lexington Books.

Tarrow, S. (2011). Power in movement: Social movements and contentious politics (3rd ed.). Cambridge University Press.

Taylor-Gibbs, J. (1987). Identity and marginality: Issues in the treatment of biracial adolescents. American Journal of Orthopsychiatry, 57(2), 265-278. https://doi.org/10.1111/j.19390025. 1987.tb03537.x

Taylor-Gibbs, J., \& Hines, A. (1992). Negotiating ethnic identity. In M. P. P. Root (Ed.), Racially mixed people in America (pp. 223-238). Sage Publications.

Telles, E. E., \& Sue, C. A. (2020). Durable ethnicity: Mexican Americans and the ethnic core. Oxford University Press.

Thompson, W. C., \& Scurich, N. (2018). When does absence of evidence constitute evidence of absence? Forensic Science International 291, e18-e19. https://doi.org/10.1016/j.forsciint.2018.08.040

Thornton, M. (1992). Is multiracial status unique? The personal and social experience. In M. P. P. Root (Ed.), Racially mixed people in America (pp. 321-325). Sage Publications.

Tilly, C. (2004). Social movements, 1768-2004. Paradigm.

Tizard, B., \& Phoenix, A. (1994). Black identity and transracial adoption. In I. Gaber \& J. Aldridge (Eds.), In the best interests of the child: Culture, identity, and transracial adoption (pp. 89102). Free Association Books.

Townsend, S., Fryberg, S. A., Wilkins, C. L., \& Markus, H. R. (2012). Being mixed: Who claims a biracial identity? Cultural Diversity \& Ethnic Minority, 18(1), 91-96.

Turner, V. (1967). The forest of symbols. Aspects of Ndembu ritual. Cornell University Press.

Viglione, L. H., \& DeFina, R. (2011). The impact of light skin on prison time for black female offenders. The Social Science Journal, 48, 250-58. https://doi.org/10.1016/j.soscij.2010.08.003

Wade, T. J., Romano, M. J., \& Blue, L. (2004). The effect of African American skin color on hiring practices. Journal of Applied Social Psychology, 34(12), 2550-2258. https://doi.org/10.1111/j.1559-1816.2004.tb01991.x

Wallace, K. R. (2001). Relative/outsider: The art and politics of identity among mixed heritage students. Greenwood/Ablex.

Wardle, F. (1987). Are you sensitive to interracial children's special identity needs? Young Children, 42(2), 53-59. https://psycnet.apa.org/record/1988-15337-001

Warren, J., \& Sue, C. A. (2011). Comparative racisms: What anti-racists can learn from Latin America. Ethnicities, 11(1), 32-58. https://doi.org/10.1177/1468796810388699

Waters, M. (2000). Multiple ethnicities and identity choices: Some implications for race and ethnic relations in the United States. In P. Spickard \& J. Burroughs (Eds.), We are a people: Narrative and multiplicity in ethnic identity (pp. 30-31). Temple University Press.

Weaver, H. (2015). Recognizing our past and moving toward our future: Decolonizing attitudes about skin color and Native Americans. Journal of Indigenous Social Development, 4(1), 1-15. https://umanitoba.ca/faculties/social_work/media/v4i1-07weaver.pdf

Wijeyesinghe, C. J. (2012). The intersectional model of multiracial identity: Integrating multiracial identity theories and intersectional perspectives on social identity. In C. L. Wijeyesinghe \& B. W. Jackson (Eds.), New perspectives on racial identity development: Integrating emerging frameworks (2nd ed.) (pp. 81-107). NYU Press. 
Daniel, G. R.

Williams-León, T., \& Nakashima, C. L. (2001). Reconfiguring race, rearticulating ethnicity. In T. Williams-León \& C. L. Nakashima (Eds.), The sum of our parts: Mixed-heritage Asian Americans (pp. 3-10). Temple University Press.

Williams, K. M. (2008). Mark one or more: Civil rights in multiracial America. University of Michigan Press.

Williams, K. M. (2017). Recursive outcomes of the multiracial movement and the end of American racial categories. Studies in American Political Development, 31(1), 88-107. https://doi.org/10.1017/S0898588X17000074

Williams, T. K., Nakashima, C. L., Kich, G. K., \& Daniel, G. R. (1996). Being different together in the university classroom: Multiracial identity as transgressive education. In M. P. P. Root (Ed.), The multiracial experience: Racial borders and the New Frontier (pp. 359-79). Sage Publications.

Wilson, T. (1992). Blood quantum: Native American mixed bloods. In M. P. P. Root (Ed.), Racially mixed people in America (pp. 3-11). Sage Publications.

Wilton, L. S., Sanchez, D. T., \& Garcia, J. A. (2013). The stigma of privilege: racial identity and stigma consciousness among biracial individuals. Race \& Social Problems, 5(1), 41-56. https://doi.org/10.1007/s12552-012-9083-5

Wright, R. D., \& Wright, S. N. (1972). A plea for a further refinement of the marginal man theory. Phylon, 33(4), 361-368. https://www.jstor.org/stable/273681

\section{Notes on Contributors}

G. Reginald Daniel is professor in the Department of Sociology at the University of California, Santa Barbara. He has published numerous books, articles, and chapters examining the topic of race and multiraciality. These include his books More Than Black? Multiracial Identity and the New Racial Order (2001), Race and Multiraciality in Brazil and the United States: Converging Paths? (2006), and Machado de Assis: Multiracial Identity and the Brazilian Novelist (2012). He also co-edited Race and the Obama Phenomenon: The Vision of a More Perfect Multiracial Union (2014). His chapters "Passers and Pluralists: Subverting the Racial Divide" and "Beyond Black and White: The New Multiracial Consciousness" appeared in Racially Mixed People in America (1992) edited by Maria P. P. Root. This was the first comprehensive examination of multiracial identity in the United States. In addition, Daniel is co-founding editor and Editor in chief of the Journal of Critical Mixed Race Studies (JCMRS) for which he coauthored "Emerging Paradigms in Critical Mixed Race Studies" (2014). 